\title{
Supplementing Rural Families through Backyard Poultry System in Bathinda District of Punjab (India)
}

\author{
Palwinder Singh*, G. S. Dhillon and A. P. S. Dhaliwal \\ Punjab Agricultural University, Ludhiana \\ Krishi Vigyan Kendra, Bathinda, India \\ *Corresponding author
}

\section{A B S T R A C T}

Keywords

Backyard poultry,

Egg production,

RIR, Rural

livelihoods

Article Info

Accepted:

05 February 2020

Available Online:

10 March 2020
Backyard poultry farming has been recognized as an effective tool for poverty alleviation in the rural families of Punjab. The level of monthly income from backyard poultry is sufficient for livelihood (20-25 birds) and an important source of supplementing earnings. It provides eggs and meat for family consumption and to some extent cash income to the family. It enhances rural livelihoods with minimum expenditure and stimulates economic growth of resource poor households in rural areas. This study was undertaken under ARYA (Attracting and Retaining Youth in Agriculture) project by Krishi Vigyan Kendra, Bathinda by introducing low input technology i.e. backyard poultry farming for small and marginal farmers. Poultry birds of breed RIR were provided to farmers. The performance of birds reared under backyard production system was quite satisfactory. The backyard poultry farming generated subsistence income and provided valuable foods that improved household nutrition.

\section{Introduction}

Livestock and Poultry provide a major contribution to Indian Economy (Nath et al., 2012). Poultry production in India emerges as a poultry industry from backyard poultry production system. Now a days the poultry product availability in the rural areas is very low/non-available due to higher prices. Therefore the consumption of egg and meat in rural areas is far below the national average. Farmer mostly reared local breeds whose growth and production potential is very low. Mandal et al., (2006) described nicely while giving a definition to a backyard poultry production system, according to them it is a low input or no input business and is characterized by indigenous night shelter system, scavenging system, with little supplementary feeding, natural hatching of 
chicks, poor productivity of birds, local marketing and no health care practice.

According to the Indian government's National Action Plan for Egg \& Poultry-2022 (NAPEP), backyard poultry accounts for 20 percent of India's poultry sector, which is worth over ₹ 800 billion. Across the country, around 30 million farmers are engaged in backyard poultry, estimates the 19th Livestock Census of India.

Rural Backyard poultry though has significant contribution in National egg production but still neglected in the consumption pattern. Seventy percent of the poultry products and eggs are consumed in urban and semi-urban areas. Poultry industry also is not able to reach to the rural poor to engage them in poultry farming. The few birds reared in rural areas are having the sequencing habit with very low housing, feeding and management facilities which results in very low profit to the families. So there is a need to develop awareness for suitable breeds under backyard along with feeding, housing and disease control practices. This can give great impact in villages to develop backyard poultry system.

The native chicken varieties adopted in freerange backyard conditions for centuries contribute about $11 \%$ of total egg production in India (Kumaresan et al., 2008). Due to their low productivity (annual egg production@ 5060 eggs/hen/year), their contribution to the total egg output was almost static for the last few decades.

The role of backyard poultry farming in sustaining and enhancing poor peoples' livelihoods in developing countries is well recognized among the developed community (Ahuja et al., 2008). There is also growing evidence to demonstrate the role of backyard poultry in enhancing the food and nutrition security of the poorest households, reducing the livelihood vulnerability and insecurity, and promotion of gender equity (Ahuja and Sen, 2007). Though, the level of monthly income from backyard poultry is low but still it is an important source of animal protein. It provides eggs and meat for family consumption and, to some extent, cash income thereby, enhances rural livelihoods. Realizing the potential offered by backyard poultry farming Krishi Vigyan Kendra, Bathinda initiated to promote backyard poultry through ARYA project. In order to stimulate economic growth of resource poor household poultry birds of dual purpose breed RIR were distributed among the small and marginal farmers in rural areas of Bathinda district. Apart from it, other common breeds like Punjab Red/ Chabbro/ Partapdhan/ Kanaknath can also be reared by the farmers.

\section{Materials and Methods}

This study was conducted in Bathinda district of Punjab, with the aim to promote Backyard poultry farming in sustaining poor people livelihoods. This study focused on the burning problem of nutritional deficiency of animal protein sources in the rural areas of Punjab and to promote backyard poultry system. Certain aspects like breed, housing, nutrition, vaccination, diseases and mortalities etc. were studied deeply.

\section{Description of study area}

The study was conducted by preparing a well structured questionnaire from the rural families of Bathinda district. Out of total eight blocks of Bathinda, five blocks were selected purposively. Out of each block, 2 villages were selected purposively on the basis of having higher number of backyard poultry birds and out of that 2 villages, 20 families from each village were selected for the present study thus comprising a total sample of 200 respondents. 


\section{Data collection}

The farming families were selected randomly by holding group meetings on village level for selection of interested rural youth for this study. Twenty birds of RIR (Rhode Island Red) were provided to each family in each village for this study period. Assessment of the families was based on well developed questionnaire regarding various aspects like feeding, breeding, management, vaccination, diseases and mortality etc. The collected data was further statistically analysed by using different statistical programmes and presented on percentage basis.

\section{Results and Discussion}

\section{Baseline data on backyard poultry production}

It is evident from the study that rural farming families are still facing the nutritional problems especially for animal protein sources. This concept of backyard poultry production enhances the nutritional value of rural poor. The distribution of twenty birds to twenty families in a village served as light house to the whole village. The performance of backyard poultry farming in the adopted villages is as below:

\section{Production performance of backyard poultry birds}

Depending upon the variable agro-climatic conditions and management system the production performance of birds varied across the study areas. Majority of the families kept poultry only on scavenging conditions which resulted in very low egg production. Feed supplementation improved the egg production and an income of Rs. 18000/- per annum was received from sale of eggs. This amount is very useful to meet out the family expenditure especially school fees, medical emergency, food security, daily expenses and other little indulgences of life. This was possible only because backyard poultry farming provided marketable surplus, to some extent, to make it worthwhile for individuals to meet essential family needs. The finding corroborate the findings of Ahuja et al., (2008), Meena et al., (2012) and Debnath et al., (2012).

\section{Benefits received through backyard poultry farming}

The poultry birds were distributed under the ARYA project to improve the backyard poultry farming in the rural families with the aim to improve the income of these families. The selected beneficiaries served as a light house to the rest community. The beneficiary farmers perceive the backyard poultry as an important livelihood enhancement factor. Each respondent had their own perception and priorities for the adoption of backyard poultry, but the overall response from this study shows that every family is interested in poultry farming and wants to remain in this field lifelong.

The data presented in table 2 revealed that backyard poultry production gives eggs \& meat with low investment which emerged as important benefit tool for farming families. The next most frequently mentioned benefit was additional source of income. Backyard poultry farming can efficiently convert waste material (insects, ants, fallen grains, green grass, kitchen waste, vegetable waste etc.) into eggs and chicken meat for human consumption was the third most perceived benefit. It was further perceived that it alleviates protein malnutrition in vulnerable groups, aids in enhancing the soil fertility and integrates well with other agricultural operations. Similar benefits were also reported by Pathak and Nath (2013), Islam et al., (2014), Patel et al., (2014) and Awasthi et al., (2015). 
Table.1 Description of selected villages in Bathinda district

\begin{tabular}{|c|c|c|c|}
\hline S. No. & Block & Village & Farming families \\
\hline \multirow[t]{2}{*}{1} & \multirow[t]{2}{*}{ Bathinda } & Jodhpur & 20 \\
\hline & & Deon & 20 \\
\hline \multirow[t]{2}{*}{2} & \multirow[t]{2}{*}{ Nathana } & Bibi wala & 20 \\
\hline & & Nathana & 20 \\
\hline \multirow[t]{2}{*}{3} & \multirow[t]{2}{*}{ Phul } & Phul & 20 \\
\hline & & Bhairupa & 20 \\
\hline \multirow[t]{2}{*}{4} & \multirow[t]{2}{*}{ Sangat } & Sangat & 20 \\
\hline & & Bajak & 20 \\
\hline \multirow[t]{2}{*}{5} & \multirow[t]{2}{*}{ Mour } & Kamalu & 20 \\
\hline & & Maisarkhana & 20 \\
\hline \multicolumn{3}{|c|}{ Total respondents } & 200 \\
\hline
\end{tabular}

Table.1 Performance of backyard poultry farming (one farming family only)

\begin{tabular}{|l|l|}
\hline Economic traits & Performance \\
\hline Average flock size (No. of birds) & 20 \\
\hline Birds sold / self consumption (No. of birds) & 10 \\
\hline Average weight of bird (g) & 2500 \\
\hline Average market price per bird (Rs) & 250 \\
\hline Eggs sold / self consumption (No.) & 1800 \\
\hline Average market price per egg (Rs.) & 10 \\
\hline Total income from eggs (Rs.) & 18000 \\
\hline
\end{tabular}

Table.2 Benefits received through backyard poultry farming

\begin{tabular}{|l|l|l|}
\hline Benefits received & Percentage & Ranking \\
\hline Alleviates protein malnutrition in vulnerable groups & 52 & IV \\
\hline Waste material can be efficiently used for human consumption & 61 & III \\
\hline Provides additional income to the rural families & 70 & II \\
\hline Integrates with agriculture & 50 & VI \\
\hline Enhancing soil fertility & 51 & V \\
\hline Provides eggs and meat & 71 & I \\
\hline Employment generation & 49 & VII \\
\hline
\end{tabular}


Table.3 Economics of Rearing 20 Birds (one farming family only)

\begin{tabular}{|l|l|}
\hline Expenditure & Amount (Rs.) \\
\hline Fixed cost (Night shelter + Feeders+ Drinkers) & 2500 \\
\hline Cost for 20 Chicks @ Rs. 30 per month old chick & 600 \\
\hline Cost on Medicine @ Rs. 10/bird & 2000 \\
\hline Cost of Feed @ 40g/bird/day for 10 weeks, feed cost @ Rs. 30/Kg & 1680 \\
\hline Total Expenditure on rearing 20 birds & $\mathbf{6 7 8 0}$ \\
\hline Income & \\
\hline Sale of Cock (50\% of total @ Rs. 250 on 24 week age) & 2500 \\
\hline Sale of eggs (180 egg/hen/year from 10 hens, sale rate Rs. 10/-) & 18000 \\
\hline Sale of culled hen @ Rs. 80 (10 hens) & 800 \\
\hline Total income & 21300 \\
\hline Net Income (Income-Expenditure) & $\mathbf{1 4 5 2 0}$ \\
\hline
\end{tabular}

Fig.1 Farmer's attitude towards Backyard Poultry

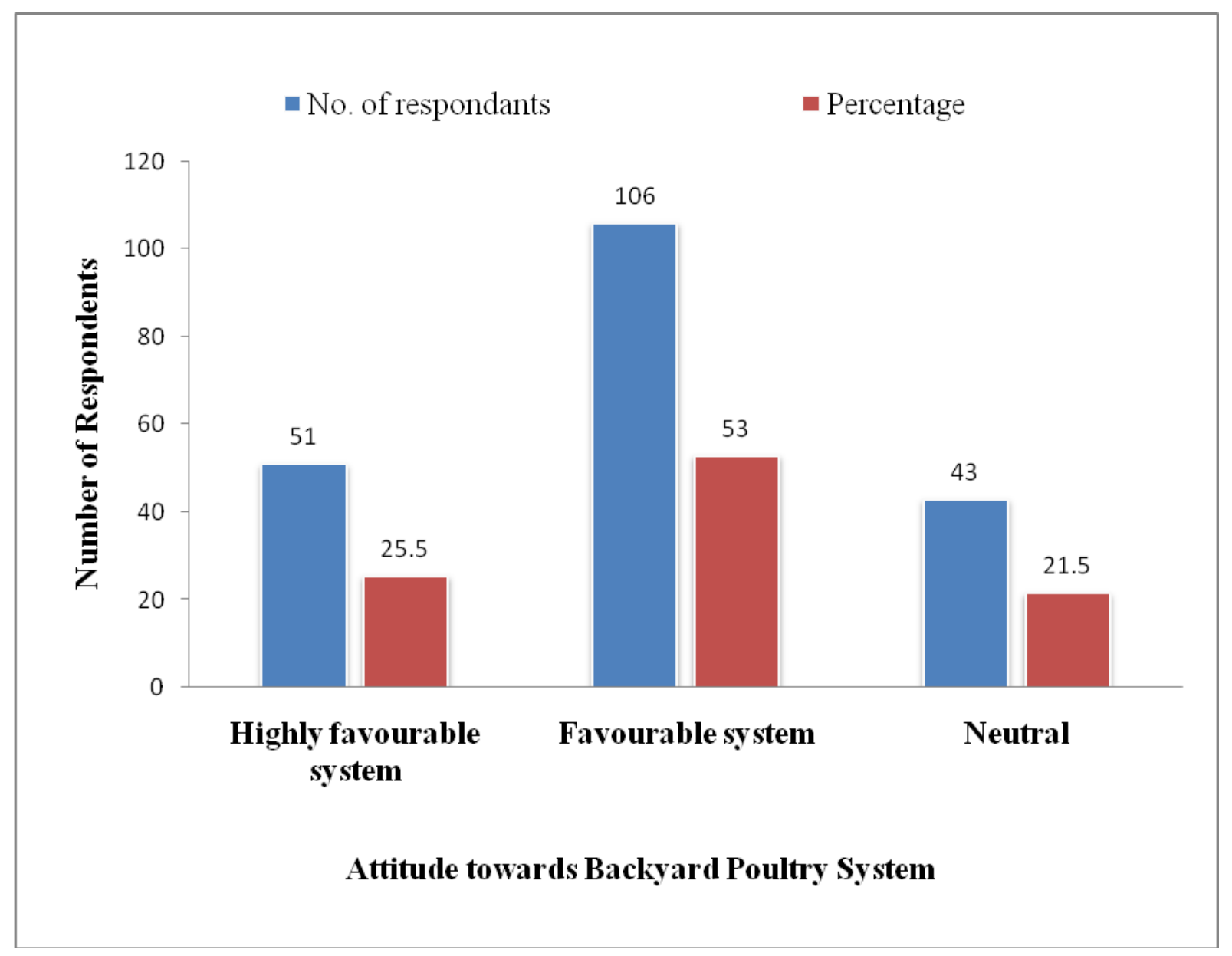


Farmer's attitude towards backyard poultry

The attitude of farmers towards backyard poultry production was measured and results presented in Figure 1:

The results showed that majority of the respondents $(53 \%)$ possessed favourable attitude towards backyard poultry system and 21.5 percent farmers showed neutral attitude. Results show that farmers were convinced with the benefits reaped from the backyard poultry rearing. However, since the highly favourable category consists of only 25.5 per cent of the respondents, it may also be assumed that the farmers are still not fully convinced that all aspects of backyard poultry farming and need more training about this aspect (Fig. 1). But they do have apprehensions on its advantages. Similar results were also reported by Kanwat (2012).

\section{Economics of Backyard Poultry farming}

As far as the economics of backyard poultry concerned, the total expenditure for rearing 20 birds was Rs. 6780/- including all input costs. Whereas the total income is in the tune of Rs. 21300/- . The annual net return of Rs. 14520/is obtained by rearing 20 birds for one year period (Table 3 ).

The income received from this business is worthwhile to cope up the family expenditures and meet out daily requirements of farming families. The farmers can increase their income by increasing the number of birds. None of the farmers faced any marketing problem as far as sale of eggs was concerned.

From the above study it is concluded that backyard poultry farming is an effective tool to strengthen the livelihood of small and marginal farmers in rural areas of Bathinda district of Punjab with low-cost initial investment. It provides eggs and meat for family consumption and additional income to the rural households. The present study has achieved its goal by initiating income generating activity in the rural farmers. Similar efforts should be made by other agencies and development departments like SFAC (Small Farmers' Agri-Business Consortium) for increasing the income of the rural peoples.

\section{Future prospect of the study}

Further these farmers want to unite as Self Help Group (SHG) to sell the desi egg in urban and semi-urban areas. This Kendra is on the door step to establish SHGs and FPOs (Farm Produce Organizations) to earn more ruminative from the existing backyard poultry.

\section{References}

Ahuja, V. and Sen, A. 2007. Viability and future of small scale commercial poultry production in developing countries. Paper presented at International Conference on Poultry in the 21st Century: Avian Influenza and Beyond, Bangkok, November 5-7.

Ahuja, V., Dhawan, M., Punjabi, M. and Maarse, L. 2008. Poultry based livelihoods of rural poor: Case of Kuroiler in West Bengal. National Dairy Development Board of Indian and Food and Agriculture Organization of the United Nations, p.57.

Awasthi, P.K., Tomar, A. and Raghuwanshi, N.K. 2015. Poverty reduction through strengthening backyard poultry farming in central India: an economic analysis. Int. J. Food, Agri. Vet. Sci., 5(1): 11-17.

Debnath, M.K., Majumder, D. and Das, P.K. 2011. Status of backyard and small 
scale poultry production to sustainable livelihood- a case study. J. Crop and Weed., 7(2): 113-115.

Dhaka, B.L., G.S. Meena, R.K. Bairwa and Meena, N.L. 2017. Supplementing Rural Livelihoods through Backyard Poultry Farming. Int.J.Curr.Microbiol. App.Sci., 6(4): 1412-1415.

Islam, R., Kalita, N. and Nath, P. 2014. Comparative performance of Vanaraja and Indigenous chicken under backyard system of rearing. J. Poultry Sci. Technol., 2(1): 22-25.

Kanwat, M., Meena, M.S., Kumar, P.S., Choudhary, V.K. and Bhagawati, R. 2012. Measurement of attitude towards the adoption of back yard poultry farming in Arunachal Pradesh. J. Agri. Sci., 4(3): 131-136.

Kumaresan, A., Bujarbaruah, K.M., Pathak, K.A. 2008. Analysis of a village chicken production system and performance of improved dual purpose chickens under a subtropical hill agroecosystem in India. Trop Anim Health Prod., 40, 395-402.

Mandal A.B., Tyagi P.K. and Shrivastav A.K. 2006. Research priorities in poultry and nurtion and feed technology to 2020. In:
Sasidhar, P.V.K (Ed.) Poultry Research priorities in 2020, Proceedings of National seminar, November 2-3, Central Avian Research Institute, Izatnagar, 96-114.

Meena, K.C., Singh, B. and Shivhare, M.K. 2012. Nutritional and livelihood security through backyard poultry for small and landless labours. Current Opinion in Agri., 1(1): 24-26.

Nath, B. G., Toppo, S., Chandra, R., Chatlod, L., \& Mohanty, A. 2012. Level of adoption and constraints of scientific backyard poultry rearing practices in rural tribal areas of Sikkim, India. Online J. of Animal and Feed Res., 2(2), 133-138.

Patel, S.K., Machhar, R.G., Kacha, H.L., Rani, R.R., Patel, G.D. and Patel, U.M. 2014. Effect of backyard poultry farming on living standard of tribal farmers in Dahod district of Gujarat, India. J. Poult. Sci. Technol., 2(4): 7983.

Pathak P.K. and Nath B.G. 2013. Rural poultry farming with improved breed of backyard chicken. J. World's Poult. Res. 3(1): 24-27.

\section{How to cite this article:}

Palwinder Singh, G. S. Dhillon and Dhaliwal, A. P. S. 2020. Supplementing Rural Families through Backyard Poultry System in Bathinda District of Punjab (India). Int.J.Curr.Microbiol.App.Sci. 9(03): 10-16. doi: https://doi.org/10.20546/ijcmas.2020.903.002 